\title{
Szemle
}

\section{BIRÓ GYULA*}

\section{A bünügyi nyomozás múltja, jelene, jövője - Monográfia a kriminalisztika tendenciáiról}

A kriminalisztikának, ennek az alig másfél évszázados múltra visszatekintő tudományterületnek nemrégiben új, a teljesség igényével készült, monografikus szintű feldolgozása jelent meg Fenyvesi Csaba tollából. ${ }^{1}$ A szerző a PTE ÁJK Büntető Eljárásjogi és Kriminalisztikai Tanszékének docense, aki közgazdasági és jogi tudományos fokozattal rendelkezik, oktatóként Arany Katedra díjat kapott, elméleti tudását pedig védőügyvédi praxisa révén tudja összekötni a gyakorlat igényeivel. Ez az ötödik önálló könyve, emellett - társszerzőségben - hat büntető-eljárásjogi és kriminalisztikai egyetemi tankönyvet jegyez. A könyvben szembetűnő kutatói alaposság sem véletlen: a szerző 2013 októberében nyújtotta be MTA doktori értekezését, amely szintén kriminalisztikai témájú.

A könyv alapfelfogása szerint a kriminalisztika a bünügyi tudományoknak az az ága, amely a büncselekmények felderítésének és bizonyításának eszközeit és módszereit tárja fel, alkotja meg, rendszerezi és alkalmazza normatív jogi kereteken belül. Az alcíme szerint a nyomozás múltját, jelenét és jövőjét tárgyaló kötet széleskörüen vizsgálja a bünügyi múltkutatás (felderítés) történeti gyökereit, kontinentális (kriminalisztikai) és angolszász (forenzikus) fogalmi rendszerének különbségeit, tudományos kapcsolódásait, krimináltechnikai és -taktikai feldolgozottságát. Forrásbázisa rendkívül gazdag, és elsősorban a szerző angolszász nyelvterületen való jártasságát mutatja. A monográfiában több száz magyar és idegen nyelvű forrásmunkát idéz a szerző, ezek között saját (magyar és idegen nyelvű) publikációinak száma is meghaladja a százat.

A kötet kitűnően szerkesztett, jól követhető logikai rendszere van. Az olvasót tematikusan, egyszersmind - szinte észrevétlenül - kronologikusan is végigvezeti a kriminalisztika tudományának fejlődésén, rendszerén, módszerein, és a lehetséges

* Dr. Biró Gyula nyá. r. alezredes, rendőrségi tanácsos, c. egyetemi docens, Debreceni Egyetem Állam- és Jogtudományi Kar, Büntető Eljárásjogi Tanszék, birogy51@freemail.hu.

1 FenYvesı Csaba: A kriminalisztika tendenciái. A bünügyi nyomozás múltja, jelene, jövője, Dialóg Campus, Budapest-Pécs, 2014, 304. 
jövőképet is felvázolja. Teszi mindezt olyan olvasmányos stílusban, hogy a - müfajmegjelölését tekintve - kézikönyvnek szánt opus egyszerre válik a legjobb értelemben vett ismeretterjesztö irodalommá, könnyen tanulható tankönyvvé és megkerülhetetlen tudományos alapmunkává. Jóllehet, az olvashatóság szempontjából kifogásolható, mára meghaladott a végjegyzetek alkalmazása, amennyiben az olvasó veszi a fáradságot, és hátralapoz a fejezetek végére, a jegyzetekben szinte egész lexikont talál általános (köztörténeti) és tudománytörténeti ismeretekből - olyan mennyiségben, amely mégiscsak igazolja a végjegyzetes szerkesztésmód választását.

A müfaji keveredés általában a szerző dolgát nehezíti meg, ám a könyv által felmutatott kvalifikációs sokszínüség (tankönyv - kézikönyv - alap (háttér)-irodalom - lexika - tudományos monográfia) azt eredményezi, hogy az olvasóközönség legszélesebb körének érdeklődésére számíthat, hiszen mindenki számára tartalmaz valami hasznosat.

Az egyetemi hallgatók jól tanulható, didaktikus tankönyvet kaptak, amely bevezeti őket e bűnügyi (az angolszász terminológiát átvéve: forenzikus) tudományterület hazai és egyetemes fejlődéstörténetébe, föbb részeibe, ezek rendszertanába (a piramismodell bemutatása és továbbfejlesztése által), alapelveibe, módszertanába és eredményeibe. A hallgatók számára a tananyag elsajátítását számos szemléltető példa, valós jogeset lényeges kriminalisztikai vonatkozásainak ismertetése teszi könnyebbé.

A munka elméleti szempontból kiemelkedő jelentőségü része a kriminalisztikai szakirodalom széles körü feldolgozása. A szerző nemcsak a (nyilvánvalóan preferált) angol nyelvterület eredményeit ismerteti meg az olvasóval, hanem a hazai kriminalisztikai szakirodalmat is a teljesség igényével tárja fel, rendszerezi és értékeli. Mindeközben felvet néhány olyan fehér foltnak minősülö területet, amelyek az új típusú bűncselekmények nyomozása során napjainkban kerültek előtérbe. A számítógépes bűnözés nyomozása, a digitális bizonyítékkal kapcsolatos eljárás, vagy a hangazonosítás mind olyan területe a kriminalisztikának, amelyekben még nem született hazánkban tudományos igényü, monografikus feldolgozás. A magyar szakirodalom értékelésének konklúziója, hogy az alapmüvek megvannak, az érdeklődés középpontjában jelenleg a krimináltechnika, az elsősorban természettudományos módszerekkel történő nyomozás áll. Arról az elmúlt hat évtizedben számos monográfia született, míg a krimináltaktika egyes részeiröl, különösen a bizonyítási kísérletröl, felismerésre bemutatásról, a kényszerintézkedésekröl vagy a valószínüségen alapuló Bayes-analízisről egyáltalán nem született még összefoglaló jellegủ magyar tudományos feldolgozás, azaz ez a terület - a nemzetközi tendenciával egyezően hazánkban sem élvez jelentős tudományos érdeklődést, és hiányzik a kutatások és eredmények igazán átütő újdonságereje is.

A könyv azonban a gyakorló nyomozóknak, a „tényészeknek” is számos, itthoni viszonylatban teljesen új kutatási eredményt szolgáltat. A legújabb nyomozási technikák, elemző módszerek és eszközök jelennek meg szigorú tematikus rendben. A gyakorlat érdeklődésére elsősorban a könyv utolsó három tematikus fejezete (a kriminalisztikai hibák rendszerezett összegyüjtése, a tudományterület fejlődésének jelenlegi tendenciáit ismertető és elemző fejezet, valamint a jövőkép felvázolása) 
tarthat számot. Amennyiben ugyanis a kriminalista nem helyesen értékeli a tényeket, elöfordulhat, hogy nem „tükröt tart” a múlt eseményeinek, hanem görbe tükörbe állítja azokat. A magyar olvasó számára még ismerősen cseng a 2002-es móri mészárlás miatt életfogytiglani szabadságvesztésre ítélt Kaiser Ede esete, akiről csak évekkel később derült ki, hogy valójában nem ő követte el a büncselekményt, hanem két másik férfi. A kriminalisztikai eszközök folyamatos fejlesztése révén, pl. a DNS-azonosítás általánossá válása útján a téves ítéletek (a justizmord) egyre inkább elkerülhetők, de legalábbis utóbb orvosolhatók. A szerző nagy szolgálatot tesz a kriminalisztikai gyakorlatnak azzal, hogy rendszerezi az angolszász és a magyar gyakorlatban előforduló tévedések tipikus okait, majd körültekintő javaslatokat tesz az ezekből eredő hibák elkerülésére, a tévedések megelőzésére. E körben kiemeli, hogy a tanúk tévedése (akár a felismerésre bemutatásnál, akár a vallomások során) a tévedések leggyakoribb oka, amelyet a bünügyi szervek elsősorban úgy tudnak kivédeni, ha a tanúvallomásokat következetesen összevetik a kriminalisztika más eszközeivel, a tárgyi bizonyítékokkal is.

A múlt megismerhető - álítja a szerző -, mégpedig a nyomok és anyagmaradványok segítségével. A „kriminalisztikai hét fö kérdés” segít ahhoz, hogy a múltat megismerjük, hogy rekonstruálhassuk. Edmond Locard a 19-20. század fordulóján alkotta meg a kriminalisztika alapelvét azzal, hogy kimondta: „Minden érintkezés nyomot hagy". Valóban, minden búncselekmény hagy nyomot. Ezeket össze kell gyüjteni, csakúgy, mint a személyi bizonyítékokat. Lényeges továbbá, hogy minden kriminalista annyit ér, amennyi adata van, az adatok tárháza pedig a helyszín. Végül kiemelendő az első csapás jelentősége: az elsődleges intézkedések azok, amelyekből kinyerhetjük, és amelyekkel megszerezhetjük a végső célunkhoz, az azonosításhoz szükséges adatokat. Az adatokat azonban mindig körültekintően kell kezelni és esetröl esetre értékelni, mert a természet soha nem ismétli önmagát. (Natura non facit saltum; 143-158. o.)

A nyomozás, nyomelemzés jelenkori tendenciáinak elemzésekor a szerző 13 jelenséget különböztet meg. Lényeges megállapítása, hogy napjaink kriminalisztikáját a krimináltechnika uralja, amit az is elösegít, hogy a büncselekmények elkövetése is egyre inkább technikai jellegűvé válik (pl. bankkártyás csalás). Az anyagok természettudományos vizsgálata és elemzése mellett a krimináltaktika háttérbe szorul. A szerző által ismertetett második tendencia a specializálódás. Már régen eljárt az idő a „polihisztor” kriminalisták fölött, a rohamosan növekvő tudásmennyiség egyszerüen kikényszeríti a specializálódást. Ezzel függ össze - bár azt a szerző (nehezen indokolhatóan) egy későbbi alfejezetben tárgyalja - a „szakértősödés”, azaz a minőségi specializálódás alapján többlettudásra szert tett szakemberek igénybevétele a nyomozásnál. A széles spektrumú általános tudásnál a kriminalisztikában sokkal hatékonyabb a vizsgálat tárgya és/vagy módszere alapján szakterületekre koncentráló, elmélyült tudás. Megjegyezzük, hogy - bár a szerző ezt a következtetést sem itt, hanem külön alfejezetben vonja le - ez a folyamat nyilvánvalóan azt eredményezi, hogy a kriminalisztika minden eddiginél inkább csapatmunkává válik.

A modern kriminalisztika az egyre kisebb részekre összpontosít. Ezt nevezi a szerző minúcializálódásnak vagy miniatürizálódásnak (211. o.). Helyénvaló megállapítása a kötetnek (Tremmel Flóriántól kölcsönözve), hogy napjaink nyomozati te- 
vékenységét az eszközbőség mellett a bizonyítékínség jellemzi, azaz egyre fogy az anyagmaradványok, nyomok mennyisége a helyszínen, emiatt felértékelődnek a puszta szemmel láthatatlan, mikroszkopikus nyomok. A nyomok pedig akár sok-sok évvel később is megvizsgálhatók, így régen lezárt nyomozások aktái is megnyithatók, megoldatlan ügyekre derül fény (mint az ismert amerikai filmsorozatokban). Fenyvesi Csaba ezt a jelenséget nevezi a múlt közeledésének, ami által a képek élesednek.

Napjaink nyomozásában (a tudás, a megismerés módszereinek fejlődése egyenes következményeként) tendenciaként jelenik meg a valószínüségi szint folyamatos erösödése is. A technikai fejlődés a szerző szerint egyre valószínübb, a bizonyoshoz, ténylegeshez egyre közelebb álló következtetésekre engedi a nyomozókat. Miközben a 19. század elején még az is kérdéses volt, vajon vér-e az a maradvány, amit a helyszínen találtak, mára a DNS-azonosítás révén teljes bizonyossággal választ kapnak a nyomozók arra is, hogy kitől származik. Az ilyenfajta bizonyosságok révén az egyéb bizonyítékok értékelése, a szakértői vélemények és más eszközök hibái is könnyebben elkerülhetők, így ez a tendencia a kriminalisztika jövőképében is fontos szerepet kap.

A kriminalisztikai tendenciák körében Fenyvesi Csaba kétirányúan értékeli a komputerizálódás („számítógépesedés”) jelenségét. A számítógépeket egyrészt a bűncselekmények elkövetési eszközeként, illetve tárgyaként közelíti meg, amely révén igazán határok nélküli bűncselekménnyé válik a csalás, a terrorcselekmény vagy a személyiséglopás, másrészt azonban kiemeli, hogy a számítógép az az eszköz, amely hihetetlen lökést adott a bűnüldözés-tudomány és a felderítés fejlődésének. Új programok segítik a nyomazonosítást, és egyre nő a komputereken tárolt és rendszerezett adatok mennyisége. Ez nemzeti és nemzetközi szinten is mind hatékonyabb bűnüldözést tesz lehetővé. Ezek alapján lehet ma már bünözési térképeket készíteni, amelyek révén a nyomozó nem utólag, „üldöző” módon, hanem egyidejüleg „olvashatja” a bűnözés aktuális helyzetét, nagyban segítve a bủnmegelőzést is. Ezt szolgálja a kiberfelderítés (a „digitkommandó”) elterjedése is, amely a bünügyi informatika kialakulásának köszönhető, és pl. az „elektronikus helyszíni szemlében” vagy az „online házkutatásokban” nyilvánul meg. Az ilyen bűncselekmények felderítésének legföbb nehézségét az elkövetés transznacionális jellege adja, amely a szerző szerint a kriminalisztika e területének rohamos további fejlödését indukálja (mind a számítógépes rendszerek és alkalmazások fejlődésével, mind a felderítés nemzetköziesedésével, nemzetközi szervezetek létrejöttével). Részben a kiberfelderítés hozza magával a titkos eszközök és módszerek felértékelődését is, amelyet Fenyvesi Csaba szintén a jelenkori kriminalisztika jelentős tendenciájaként ragad meg. A jelenkori tendenciákat számba vevő fejezet a bűnmegelőzés és bűnüldözés privatizálódásával zárul. A szerző szerint ugyanis napjainkban egyre szaporodnak a magánszektorba tartozó olyan szervezetek, amelyek a nyomozókkal, bünügyi hatóságokkal biztonsági partnerségi viszonyban vannak.

A kötet legizgalmasabb fejezete a kriminalisztika jövőbeni lehetőségeit vázoló, elemző IX. rész, amellyel a szerző valóban a krimisorozatokból ismert jelenségek valós rejtelmeibe vezeti be az olvasót. Értekezik például arról, hogy mennyire bizonytalan a kutya (a „biodetektív”) általi emberi szagazonosítás, és hogy lehetne-e 
ezt a jövőben a technikai fejlesztések segítségével müorral helyettesíteni. Ír arról is, hogy a régóta használt hazugságvizsgálót (poligráfot) felválthatja a monoscanner, azaz az agyolvasó vagy más, az igazmondás, öszinteség ellenőrzésére alkalmas eszköz (hőkamera, pszichológiai stresszérzékelö, hangelemző stb.). Szól a digitális felderítésről és a mobil helyszíni laborok jelentőségéről, és azt vélelmezi, hogy a jövőben is inkább a technikai fejlesztések lesznek hangsúlyosak, nem pl. a - szerző szerint egyébként szintén fejlesztendő - profilalkotás. Záró megállapítása, hogy minden fejlesztési javaslat és irány csak akkor lehet eredményes és hasznos, ha a természettudományok széles körü alkalmazása mellett is meghatározó marad a kriminalista személye, aki a gépek és természettudományos eljárások eredményeit értőn és felelősséggel használja a búncselekmények felderítésekor.

A kötetröl - az eddigi értékeléssel igazolhatóan - méltán állapíthatjuk meg, hogy az egyértelmüen hiánypótló alkotás a hazai kriminalisztikatudományban. Ez idáig nem született a kriminalisztika elméletével és gyakorlatával egyszerre foglalkozó, ehhez hasonlóan átfogó, a tudományos eredmények gyakorlati bűnüldözésben való hasznosítására koncentráló, tematikus monográfia. 